\title{
Raoultella ornithinolytica urinary tract infection in a pediatric patient with T-cell precursor acute lymphoblastic leukemia
}

\author{
Ma. Camila Prada-Avella1 ${ }^{1}$, Miguel A. Luengas-Monroy², Amaranto Suárez¹, Liliana M. Mora-Ramírez ${ }^{3}$, and \\ Álvaro A. Faccini-Martínez ${ }^{4,5 *}$ \\ ${ }^{1}$ Servicio de Hematología-Oncología Pediátrica, Instituto Nacional de Cancerología, Bogotá, Colombia; ${ }^{2}$ Servicio de Infectología pediátrica, Instituto \\ Nacional de Cancerología, Bogotá, Colombia; ${ }^{3}$ Unidad de Microbiología Clínica, Instituto Nacional de Cancerología, Bogotá, Colombia; ${ }^{4}$ Department \\ of Pathology, University of Texas Medical Branch, Galveston, Texas, USA; ${ }^{5}$ Comité de Medicina Tropical, Zoonosis y Medicina del Viajero, Asociación \\ Colombiana de Infectología, Bogotá, Colombia
}

\begin{abstract}
Background: Currently, Raoultella ornithinolytica is considered an emerging pathogen of community- and hospital-acquired infection, particularly in patients with immunodeficiencies, malignancies, anatomical abnormalities, or after invasive procedures. Pediatric infections with $R$. ornithinolytica are exceedingly rare, with only six previously reported cases, of which only two were reported as a urinary tract infection. Case report: Here, we describe a polymicrobial urinary tract infection (R. ornithinolytica and Enterococcus faecalis) in a pediatric patient with T-cell precursor acute lymphoblastic leukemia, which was successfully treated with ampicillin-sulbactam. Conclusions: To the extent of our knowledge, we report the seventh case in a pediatric patient and only the third case of a urinary tract infection in this age group caused by $R$. ornithinolytica.
\end{abstract}

Keywords: Urinary tract infection. Pediatrics. Precursor T-Cell lymphoblastic leukemia-lymphoma. Colombia.

\section{Infección de vías urinarias por Raoultella ornithinolytica en un paciente pediátrico con leucemia linfoblástica aguda de células $T$}

\section{Resumen}

Introducción: Actualmente Raoultella ornithinolytica es considerado un patógeno emergente involucrado en infecciones adquiridas en la comunidad y en el hospital, en particular en pacientes con algún tipo de inmunodeficiencia, malignidad, alteraciones anatómicas o sometidos a procedimientos invasivos. Las infecciones pediátricas causadas por R. ornithinolytica son sumamente raras, con solo seis casos publicados, de los cuales nada más dos se presentaron como infección de vías urinarias. Caso clínico: Se describe una infección de vías urinarias polimicrobiana (R. ornithinolytica y Enterococcus faecalis) en un paciente pediátrico con leucemia linfoblástica aguda de células $T$, que fue tratado satisfactoriamente con ampicilina-sulbactam. Conclusiones: Con base en lo que se sabe hasta el momento, se reporta el séptimo caso en un paciente pediátrico y el tercer caso de infección de vías urinarias causada por R. ornithinolytica en este grupo de edad.

Palabras clave: Infección del tracto urinario. Pediatría. Leucemia linfoblástica de células T. Colombia.

\section{Correspondence:}

*Álvaro A. Faccini-Martínez

E-mail: afaccini@gmail.com
Date of reception: 05-09-2020

Date of acceptance: $12-10-2020$

DOI: 10.24875/BMHIM.20000280
Available online: 08-06-2021

Bol Med Hosp Infant Mex. 2021;78(4):346-349

www.bmhim.com 1665-1146/@ 2020 Hospital Infantil de México Federico Gómez. Published by Permanyer. This is an open access article under the CC BY-NC-ND license (http://creativecommons.org/licenses/by-nc-nd/4.0/). 


\section{Introduction}

The genus Raoultella, which belongs to the Enterobacteriaceae family, encompasses encapsulated Gram-negative, oxidase-negative, catalase-positive, aerobic, and non-motile bacillii,2. Initially, it was classified in the genus Klebsiella. However, in 2001, with phylogenetic testing including $16 \mathrm{~S}$ rRNA and $r p o B$ sequence analysis, the genus Klebsiella was further divided into two genera: the genus Raoultella and cluster II of the genus Klebsiella was transferred and renamed within the new genus ${ }^{3}$. Currently, Raoultella planticola and Raoultella ornithinolytica are the most important species because of their association as pathogenic agents ${ }^{1,2}$.

$R$. ornithinolytica has been found in water environments, soil, insects, fish, ticks, and termites, but human infections are rare ${ }^{2}$. The first human infection caused by $R$. ornithinolytica was reported in $2009^{4}$ and it is currently considered an emerging pathogen of community and hospital-acquired infection, particularly in patients with immunodeficiencies, malignancies, anatomic abnormalities, or after invasive procedures ${ }^{2,5}$. Gastrointestinal and hepatobiliary infections are among the most frequently reported infections in the literature. However, urinary tract infections, wound and skin infections, bacteremia, respiratory infections, bone and joint infections, central nervous system infections, mediastinitis, pericarditis, conjunctivitis, and otitis have also been reported in adults ${ }^{2,5,6}$. Pediatric infections with $R$. ornithinolytica are exceedingly rare, and only six cases have been reported previously ${ }^{7-11}$, of which two cases were reported for urinary tract infection ${ }^{10,11}$. Here, we describe a case of $R$. ornithinolytica urinary tract infection in a pediatric patient with T-cell precursor acute lymphoblastic leukemia.

\section{Clinical case}

A 9-year-old male patient was brought to the emergency department because of emetic syndrome, asthenia, adynamia, and weakness, without fever. A medical history of T-cell precursor acute lymphoblastic leukemia was recorded. Mild to moderate dehydration was identified with no other physical findings. Laboratory tests revealed moderate hypokalemia $(2.8 \mathrm{mEq} / \mathrm{L})$, pancytopenia (white blood cell count of 400 cells $/ \mathrm{mm}^{3}$, red blood cell count of 2.84 million cells $/ \mathrm{mm}^{3}$, platelet count of 23,000 cells $/ \mathrm{mm}^{3}$ ), severe neutropenia (50 cells/ $\mathrm{mm}^{3}$ ), lymphopenia $\left(340\right.$ cells $/ \mathrm{mm}^{3}$ ), and hemoglobin of $6.7 \mathrm{~g} / \mathrm{dL}$, requiring red blood cell and platelet transfusions. C-reactive protein was $5.6 \mathrm{mg} / \mathrm{dL}$, while liver enzymes and kidney function tests were normal. Fresh, spontaneous urine was collected. A urinalysis revealed negative nitrites, positive leukocytes, positive blood, 10 white blood cells/hpf, 250 red blood cells/hpf, $1+$ bacteria, with the remaining parameters within normal limits. Urine and blood samples were sent for culture and sensitivity, and intravenous empiric treatment with cefepime (150 mg/kg/day) was initiated. Gramnegative bacillus and Gram-positive cocci were detected in the Gram-strain of the urine. The colony number was $100,000 \mathrm{cfu} / \mathrm{mL}$ for both bacteria on the CHROMagar Orientation Medium ${ }^{\mathrm{TM}}$ (Becton Dickinson, Germany). Through VITEK ${ }^{\circledR} 2 \times L$ (Biomerieux, France), the urine culture isolate was identified as Raoultella ornithinolytica and Enterococcus faecalis, and antimicrobial susceptibilities were tested. The $R$. ornithinolytica and $E$. faecalis demonstrated susceptibility to all tested antibiotics, including ampicillin-sulbactam (Table 1). The blood culture set (two aerobic and two anaerobic bottles) was negative. Treatment was changed to intravenous ampicillin-sulbactam $(50 \mathrm{mg} /$ $\mathrm{kg}$ ) every $6 \mathrm{~h}$ to complete a total duration of 7 days of treatment. The patient's clinical condition improved, and all symptoms resolved. After appropriate antibiotic treatment and achievement of negative urine culture, the patient was discharged.

\section{Discussion}

Here, we report the seventh case in a pediatric patient and the third pediatric case of urinary tract infection caused by $R$. ornithinolytica. As in this case (male child with T-cell precursor acute lymphoblastic leukemia), all the six previously published pediatric cases were diagnosed in patients with either immunodeficiency (asplenia) ${ }^{7}$, malignancies (retinoblastoma and acute myeloid leukemia) ${ }^{8,9}$, anatomical abnormalities (bilateral vesicoureteral reflux and hydronephrosis) ${ }^{10,11}$, or other comorbidities (IgA nephropathy) ${ }^{9}$. This clinical pattern is in line with the most extensive series of $R$. ornithinolytica infections in adults, which described comorbidities in more than $50 \%$ of patients ${ }^{5,12}$. Therefore, more extensive studies are needed to a better understanding of the clinical features of $R$. ornithinolytica in childhood to confirm which comorbidities are risk factors.

Only one of the previously reported pediatric cases showed polymicrobial infection: a case of a febrile 8-year-old female patient with a history of retinoblastoma, neurogenic bladder, and frequent urinary tract infections $^{8}$. Blood and urine cultures yielded 
Table 1. Antimicrobial susceptibility of Raoultella ornithinolytica and Enterococcus faecalis using VITEK ${ }^{\circledR} 2$ $\mathrm{XL}$ (Biomerieux, France)

\begin{tabular}{|c|c|c|}
\hline \multicolumn{3}{|l|}{ Raoultella ornithinolytica } \\
\hline Antimicrobial & MIC $(\mu \mathrm{g} / \mathrm{mL})$ & $\begin{array}{l}\text { Susceptibility } \\
\text { interpretation }\end{array}$ \\
\hline Amikacin & $\leq 2$ & Susceptible \\
\hline Ampicillin-sulbactam & 4 & Susceptible \\
\hline Cefepime & $\leq 1$ & Susceptible \\
\hline Cefoxitin & $\leq 4$ & Susceptible \\
\hline Ceftazidime & $\leq 1$ & Susceptible \\
\hline Ceftriaxone & $\leq 1$ & Susceptible \\
\hline Ciprofloxacin & $\leq 0.25$ & Susceptible \\
\hline Doripenem & $\leq 0.12$ & Susceptible \\
\hline Ertapenem & $\leq 0.5$ & Susceptible \\
\hline Gentamicin & $\leq 1$ & Susceptible \\
\hline Imipenem & $\leq 0.25$ & Susceptible \\
\hline Meropenem & $\leq 0.25$ & Susceptible \\
\hline Piperacillin-tazobactam & $\leq 4$ & Susceptible \\
\hline \multicolumn{3}{|l|}{ Enterococcus faecalis } \\
\hline Antimicrobial & MIC $(\mu \mathrm{g} / \mathrm{mL})$ & $\begin{array}{r}\text { Susceptibility } \\
\text { interpretation }\end{array}$ \\
\hline Ampicillin & $\leq 2$ & Susceptible \\
\hline Penicillin G & 2 & Susceptible \\
\hline Ciprofloxacin & 1 & Susceptible \\
\hline Daptomycin & 1 & Susceptible \\
\hline Teicoplanin & $\leq 0.5$ & Susceptible \\
\hline Tetracycline & $\leq 1$ & Susceptible \\
\hline Vancomycin & $\leq 0.5$ & Susceptible \\
\hline
\end{tabular}

MIC, minimum inhibitory concentration.

R. ornithinolytica and Proteus mirabilis ${ }^{8}$. The present report describes a polymicrobial urinary tract infection (R. ornithinolytica and E. faecalis). Regarding the most extensive series of $R$. ornithinolytica infections, Chun et al. (2015) and Seng et al. (2016) described $31 \%$ and $17 \%$ polymicrobial infection in adults associated with $E$. faecalis in $19 \%$ and $16 \%$, respectively ${ }^{5,12}$. Whether polymicrobial infections are related to more or less severe disease in $R$. ornithinolytica infection is an interesting hypothesis that requires further investigation.
Interestingly, although Raoultella spp. exhibited intrinsic resistance to ampicillin (similarly to some Klebsiella species) because of chromosomally encoded beta-lactamases ${ }^{2}$, we achieved a satisfactory treatment using ampicillin-sulbactam. This outcome could be explained by Walckenaer et al. findings, who observed that a combination of amino- and carboxypenicillin with clavulanic acid makes $R$. ornithinolytica environmental isolates susceptible to these molecules ${ }^{13}$. As ampicillin-sulbactam is an aminopenicillin combination with an inhibitor of bacterial beta-lactamase (as well as clavulanic acid), these characteristics support our results. In any case, this hypothesis must be confirmed in further studies.

Finally, in Colombia, only a few previous studies have reported Raoultella spp. infections. In 2012, Molano et al. described bacterial isolations of urinary tract infection in women with urethral catheters from Bogotá city and Soacha municipality and found $R$. ornithinolytica $<3 \%$ of the urine cultures ${ }^{14}$. Later, in 2016, Márquez-Herrera et al. described the clinical characteristics of patients with carbapenemase-producing Klebsiella isolates in a tertiary pediatric hospital between 2012 and 2015 in Bogotá, reporting only one case of "Klebsiella ornithinolytica" bacteremia in a patient with nephrotic syndrome ${ }^{15}$. The last report was published in 2017, where RamírezQuintero et al. described a 41-year-old female patient from Medellín city with community-acquired $R$. planticola bacteremia of gastrointestinal origin ${ }^{16}$. While the first two studies used API 20E and VITEK (probably VITEK Legacy), respectively, as phenotypic identification systems ${ }^{14,15}$, Ramírez-Quintero et al. used the VITEK 2 system $^{16}$. Moreover, Park et al. evaluated the ability of three phenotypic systems (VITEK 2, MicroScan, and API 20E) to identify $R$. ornithinolytica and found that only VITEK 2 was able to identify all the isolates correctly ${ }^{17}$. Thus, since we used the VITEK2 system, our microbiological identification was accurate and reliable.

In conclusion, this case report describes a polymicrobial urinary tract infection (R. ornithinolytica and $E$. faecalis) in a pediatric patient with T-cell precursor acute lymphoblastic leukemia, which was successfully treated with ampicillin-sulbactam. We highlight the importance of considering $R$. ornithinolytica as an emerging pathogen in pediatric patients and the use of reliable diagnostic methods for accurate microbiological identification.

\section{Ethical disclosures}

Protection of human and animal subjects. The authors declare that no experiments were performed on humans or animals for this study. 
Confidentiality of data. The authors declare that they have followed the protocols of their work center on patient data publication.

Right to privacy and informed consent. The authors have obtained the written informed consent of the patients or subjects mentioned in the article. The corresponding author has this document.

\section{Conflicts of interest}

The authors declare no conflict of interest.

\section{Funding}

None.

\section{Acknowledgments}

We thank Jordan Cahn for the English review and correction of the manuscript.

\section{References}

1. Castillo-Macías A, Flores-Aréchiga A, Llaca-Díaz J, Pérez-Chávez F Casillas-Vega N. Microbiología del género Raoultella, características clínicas y dificultades para su diagnóstico. Rev Med Inst Mex Seguro Soc. 2018;56:486-90

2. Hajjar R, Ambaraghassi G, Sebajang H, Schwenter F, Su SH. Raoultella ornithinolytica: emergence and resistance. Infect Drug Resist. 2020; 13:1091-104.
3. Drancourt M, Bollet C, Carta A, Rousselier P. Phylogenetic analyses of Klebsiella species delineate Klebsiella and Raoultella gen. nov., with description of Raoultella ornithinolytica comb. nov., Raoultella terrigena comb. nov. and Raoultella planticola comb. nov. Int J Syst Evol Microbiol. 2001:51:925-32.

4. Morais VP, Daporta MT, Bao AF, Campello MG, Andrés GQ. Enteric fever-like syndrome caused by Raoultella ornithinolytica (Klebsiella ornithinolytica). J Clin Microbiol. 2009;47:868-9.

5. Seng P, Boushab BM, Romain F, Gouriet F, Bruder N, Martin C, et al. Emerging role of Raoultella ornithinolytica in human infections: a series of cases and review of the literature. Int $J$ Infect Dis. 2016;45:65-71.

6. Zheng B, Zhang J, Ji J, Fang Y, Shen P, Ying C, et al. Emergence of Raoultella ornithinolytica coproducing IMP-4 and KPC-2 carbapenemases in China. Antimicrob Agents Chemother. 2015;59:7086-9.

7. Mau N, Ross LA. Raoultella ornithinolytica bacteremia in an infant with visceral heterotaxy. Pediatr Infect Dis J. 2010;29:477-8.

8. Sękowska A, Dylewska K, Gospodarek E, Bogiel T. Catheter-related blood stream infection caused by Raoultella ornithinolytica. Folia Microbiol (Praha). 2015;60:493-5.

9. Yamakawa K, Yamagishi Y, Miyata K, Shimomura Y, Iwata A, Hori T, et al. Bacteremia caused by Raoultella ornithinolytica in two children. Pediatr Infect Dis J. 2016;35:452-3.

10. De Petris L, Ruffini E. Roultella ornithinolytica infection in infancy: a case of febrile urinary tract infection. CEN Case Rep. 2018;7:234-6.

11. Büyükcam A, Liste Ü, Bıçakçıgil A, Kara A, Sancak B. A case of Raoultella ornithinolytica urinary tract infection in a pediatric patient. J Infect Chemother. 2019;25:467-9.

12. Chun S, Yun JW, Huh HJ, Lee NY. Clinical characteristics of Raoultella ornithinolytica bacteremia. Infection. 2015;43:59-64.

13. Walckenaer E, Poirel L, Leflon-Guibout V, Nordmann P, Nicolas-Chanoine MH. Genetic and biochemical characterization of the chromosomal class A beta-lactamases of Raoultella (formerly Klebsiella) planticola and Raoultella ornithinolytica. Antimicrob Agents Chemother. 2004;48:305-12.

14. Molano G, Bayona M, Hinestroza L, Jiménez J, Luna W, Moncada M, et al. Infección por bacterias de vías urinarias en mujeres tratadas con catéter uretral y resistencia bacteriana a antibióticos. Rev UDCA Act Div Cient. 2012;15:27-34.

15. Márquez-Herrera K, Rojas-Vega A, Camacho-Moreno G. Caracterización de pacientes con aislamiento de Klebsiella productora de carbapenemasa en un hospital pediátrico de tercer nivel de Bogotá, Colombia. Infectio. 2016;20:231-7.

16. Ramírez-Quintero JD, Chavarriaga-Restrepo A. Bacteriemia por Raoultella planticola de origen gastrointestinal. latreia. 2017;30:67-71.

17. Park JS, Hong KH, Lee HJ, Choi SH, Song SH, Song K, et al. Evaluation of three phenotypic identification systems for clinical isolates of RaoulteIla ornithinolytica. J Med Microbiol. 2011;60:492-9. 